\title{
KOMUNIKASI MATEMATIS MELALUI KOOPERATIF NUMBERED HEAD TOGETHER DAN THINK PAIR SHARE
}

\author{
Bedilius Gunur $^{1^{*}}$, Karolina Santi ${ }^{2}$ \\ ${ }^{1,2}$ Universitas Katolik Indonesia Santu Paulus Ruteng \\ * Corresponding Author. Email: gbedilius@ gmail.com \\ Received: 01 Agustus 2019; Revised: 18 Agustus 2019 ; Accepted: 30 September 2019
}

\begin{abstract}
ABSTRAK
Penelitian ini bertujuan untuk; 1) mendeskripsikan keefektifan model pembelajaran kooperatif tipe NHT terhadap kemampuan komunikasi matematis siswa kelas XI Teknik Pengelasan SMK Santo Aloisius Ruteng; 2) mendeskripsikan keefektifan model pembelajaran kooperatif tipe TPS efektif terhadap kemampuan komunikasi matematis siswa kelas XI Teknik Pengelasan SMK Santo Aloisius Ruteng; 3) membandingkan efektivitas model pembelajaran kooperatif tipe NHT dengan model pembelajaran TPS terhadap kemampuan komunikasi matematis siswa kelas XI Teknik Pengelasan SMK Santo Aloisius Ruteng. Desain penelitian yang digunakan adalah The Non Eqivalen Control Desain. Populasi penelitian ini adalah seluruh siswa kelas XI Teknik Pengelasan SMK Santo Aloisius dengan jumlah 60 orang yang tersebar dalam 2 kelas. Pengambilan sampel kelas dilakukan menggunakan teknik nonprobability sampling, dengan terlebih dahulu dilakukan uji kesetaraan kelas. Data dikumpulkan dengan menggunakan instrumen yang berbentuk uraian dan menggunakan teknik tes. Sebelum melakukan teknik analisis dengan menggunakan uji $t$ terlebih dahulu dilakukan uji prasyarat analisis yaitu uji homogenitas dan uji normalitas. Hasil penelitian menunjukan, 1) model pembelajaran NHT efektif terhadap kemampuan komunikasi matematis siswa, 2) model pembelajaran TPS efektif terhadap kemampuan komunikasi matematis siswa, dan 3) model pembelajaran NHT lebih efektif daripada TPS ditinjau dari kemampuan komunikasi matematis siswa.

Kata Kunci: NHT, TPS, Komunikasi Matematis

How to Cite: Gunur, B,. Santi, K.. (2019). Komunikasi Matematis Melalui Kooperatif Numbered Head Together dan Think Pair Share. Histogram: Jurnal Pendidikan Matematika, 3(2), 108 - 121, doi: http://dx.doi.org/10.31100/histogram.v3i2.417

Permalink/DOI: http://dx.doi.org/10.31100/histogram.v3i2.417
\end{abstract}

\section{PENDAHULUAN}

Komunikasi berperan penting dalam setiap aktivitas manusia. Tanpa komunikasi, manusia tidak bisa saling berinteraksi, dan tidak dapat memahami apa yang dimaksudkan oleh orang lain. Demikian pula dalam pembelajaran matematika, komunikasi dapat dipahami sebagai proses penyampaian pesan dari sumber pesan melalui saluran/media tertentu ke penerima pesan baik secara lisan maupun dengan tertulis. (Asnawati, 2013; Rahmi, Nadia, Hasibah, \& Hidayat, 2017; Susanto, 2016) mengatakan bahwa aktivitas belajar mengajar pada hakikatnya adalah aktivitas mengkomunikasikan yaitu aktivitas 


\section{Histogram: Jurnal Pendidikan Matematika, 3 (2), 2019 - 109 Bedilius Gunur, Karolina Santi}

penyampaian ide atau gagasan atau interaksi dari sumber pesan melalui media tertentu ke penerima pesan. (Supriyadi, Suharto, \& Hobri, 2017; NCTM, 2000) melalui kegiatan

komunikasi, siswa dapat berinteraksi, bertukar gagasan dan sekaligus mengklarifikasi pemahaman dan pengetahuan yang mereka peroleh dalam pembelajaran.

(NCTM, 2000; Surya, Juniati, \& Syahputra, 2018; Hirschfeld-cotton, 2008) menyatakan apabila siswa mengembangkan komunikasi maka mereka dapat menjadi pemikir matematika yang lebih baik. Oleh sebab itu, komunikasi matematis perlu ditingkatkan agar bisa bertukar gagasan dan pengetahuan yang berlangsung di kelas. Sedangkan (Purnama, Aldila, \& Stkip, 2016; Firdaus, 2019) melalui komunikasi, ide matematika sebagai hasil dari konstruksi siswa dapat dieksploitasi dalam berbagai perspektif seperti mempertajam cara berfikir, pertumbuhan pemahaman dapat diukur, pemikiran siswa dapat dikonsolidasikan dan diorganisir pengetahuan matematika, pengembangan masalah siswa dapat ditingkatkan dan komunikasi matematika dapat dibentuk sesuai dengan tingkatan atau jenjang pendidikan maka tingkat kemampuan komunikasi matematika menjadi beragam.

Kemampuan komunikasi sangat penting dikuasai oleh siswa, karena dengan kemampuan komunikasi yang baik maka pembelajaran dapat dijalankan dengan baik, mudah untuk dimengerti atau dipahami dan tujuan pembelajaran bisa dicapai secara baik pula. Dengan komunikasi guru dapat mengidentifikasi sejauh mana kemampuan siswa tentang suatu konsep atau pemahaman matematisnya. Kemampuan siswa dalam menyampaikan ide atau gagasan dalam menyelesaikan masalah-masalah matematis baik secara lisan maupun tertulis mencerminkan kemampun komunikasi matematis seorang siswa. (Gunur, Makur, \& Ramda, 2018; Marthaulina, Siahaan, \& Napitupulu, 2012; Pratiwi, 2015) mengatakan bahwa esensi matematika dan pemikiran matematis berkaitan dengan ide, struktur, dan informasi dalam bentuk simbol dan untuk mengembangkannya, kita memerlukan komunikasi matematis untuk memfasilitasinya. Jadi, kemampuan siswa dalam berkomunikasi adalah penting dalam pembelajaran matematika.

Pada kenyataan yang terjadi di sekolah, masih banyak siswa menganggap bahwa bidang studi matematika adalah pelajaran yang sulit untuk dipahami, sehingga siswa tidak termotivasi untuk mempelajari matematika. Selain itu, pembelajaran matematika masih cendrung berpusat pada guru. Pembelajaran yang berlangsung di dalam kelas hanya menekankan aspek menghafal konsep, dan belum menyentuh aspek kemampuan komunikasi matematis. Hal ini terlihat dari proses dan hasil penyelesaian tiga buah soal cerita yang diberikan kepada siswa untuk diselesaikan. Ketiga soal itu adalah: (1) Waktu 


\section{Histogram: Jurnal Pendidikan Matematika, 3 (2), 2019 - 110 Bedilius Gunur, Karolina Santi}

yang diperlukan oleh sekelompok siswa untuk menyelesaikan sebuah soal matematika adalah 5 menit. Catatan waktu pengerjaan lebih cepat atau lebih lambat 3 menit dari waktu rata-rata. Tulislah sebuah persamaan untuk menampilkan situasi ini, kemudian selesaikan untuk menentukan waktu tercepat dan waktu terlama! (2) Jumlah usia Rio dan Soro adalah 34 tahun (Rio lebih tua dari Soro). Selisih usia mereka adalah 2 tahun. Tentukan usia mereka masing-masing! (3) Jumlah 2 bilangan adalah 195. Sedangkan selisihnya adalah 55. Tentukan kedua bilangan itu!

Jumlah siswa yang mengerjakan soal yaitu 33 siswa. Sembilan siswa diantaranya mengerjakan soal dengan benar dan memenuhi KKM $(K K M=65)$, sementara dua puluh empat siswa lainnya tidak memenuhi KKM. Persentase jawaban siswa yang memenuhi KKM dan siswa yang tidak memenuhi KKM, yaitu 27,27\% memenuhi KKM, dan 72,73\% yang tidak memenuhi KKM. Terlihat bahwa kemampuan siswa dalam menyatakan masalah kedalam model matematika masih rendah. Siswa kurang mampu menyajikan ide matematis secara tertulis, kemudian siswa kurang mampu menggunakan representasi matematika untuk menyatakan informasi matematis dari situasi atau masalah. Siswa tidak menuliskan langkah-langkah yang sistematis dalam mengerjakan soal, sehingga siswa hanya langsung membuat jawaban akhir. Hal ini menunjukkan kemampuan komunikasi matematis siswa masih rendah.

Rendahnya kemampuan komunikasi matematis siswa disebabkan oleh beberapa faktor. Salah satunya adalah model pembelajaran yang diterapkan di sekolah masih belum mefasilitasi siswa dalam melatih dan mengembangkan keterampilan komunikasi. Proses pembelajaran lebih mengarahkan pada pencapain materi dengan mengabaikan proses interaksi antar siswa seperti kerjasama, menyatakan ide-ide matematis, mengajukan pertanyaan dan menanggapi pertanyaan atau pendapat siswa lain. Hal ini berdampak pada siswa menjadi pasif, siswa menghafal konsep tanpa memahami bagaimana menemukan konsep dari materi yang dipelajari.

Untuk mengatasi masalah tersebut, diperlukan model pembelajaran yang dapat memfasilitasi dan mengembangkan kemampuan komunikasi matematis. Pembelajaran kooperatif merupakan salah satu model pembelajaran yang memberikan kesempatan kepada siswa untuk berinteraksi dan berpartisipasi aktif selama pembelajaran berlangsung(Gunur, Ramda, \& Makur, 2019). Hal ini sesuai dengan (Muchlis, Komara, Kartiwi, Hendriana, \& Hidayat, 2018; Hadi \& Kasum, 2015; Purnama et al., 2016; Abdul Qohar \& Sumarmo, 2013) menyatakan model pembelajaran kooperatif yang dapat meningkatkan kemampuan komunikasi matematis siswa. Trianto, 2013; Marthaulina et al., 


\section{Histogram: Jurnal Pendidikan Matematika, 3 (2), 2019 - 111 Bedilius Gunur, Karolina Santi}

2012) menegaskan bahwa Numbered Head Together (NHT) atau penomoran berpikir bersama merupakan salah satu pembelajaran kooperatif yang didesain untuk mempengaruhi pola interaksi siswa dan sebagai alternatif terhadap struktur kelas tradisional. Pembelajaran kooperatif tipe NHT merupakan model pembelajaran berkelompok yang setiap anggota kelompoknya saling bertanggung jawab. Setiap siswa dibentuk dalam kelompok kecil serta mempunyai nomor atau penomoran berpikir. Setiap kelompok mempunyai tujuan bersama untuk mencari dan memecahkan permasalahan matematika yang dihadapi.

Dalam kelompok NHT, semua siswa harus bekerja sama dan bertanggung jawab dalam menemukan jawaban atau solusi atas permasalahan yang disajikan. Selain itu, setiap siswa dalam kelompok NHT harus mampu mempertanggungjawabkan atau memperesentasikan, memaparkan hasil pekerjaan didepan teman-teman atau kelompok lain baik secara tertulis maupun secara lisan. Melalui proses seperti yang telah dijelaskan diyakini NHT dapat mefasilitasi dalam mengembangkan kemampuan komunikasi siswa.

Menurut (Kusuma \& Maskuroh, 2018; Marthaulina et al., 2012) NHT mempunyai kelebihan yaitu dapat meningkatakan kerjasama diantara siswa, tanggungjawab siswa secara bersama, melatih siswa untuk menyatukan pikiran, melatih siswa untuk menghargai pendapat orang lain, sebab dari hasil diskusi dimintai tanggapan dari peserta lain. Dalam pembelajaran tipe NHT sangat menyenangkan dan kreatif bagi siswa dan mengutamakan adanya kerja sama antarsiswa dan kelompok untuk mencapai tujuan pembelajaran, juga dapat memotivasi siswa lain yang kurang aktif selama berlangsungnya pembelajaran.

Selain NHT, Think Pair Share (TPS) juga merupakan model pembelajaran kooperatif yang dapat meningkatkan kemampuan komunikasi matematis siswa. Shoimin (2014) mengatakan bahwa Think Pair Share adalah suatu model pembelajaran kooperatif yang memberi siswa waktu untuk berpikir dan merespon serta saling bantu satu sama lain. (Lee, Li, \& Shahrill, 2018; Miratika, Asmin, Mulyono, \& Minarni, 2018) "mendefinisikan teknik Think-Pair-Share sebagai siklus diskusi multi-mode yang dibagi menjadi tiga tahap: (1) 'Think': siswa diberi kesempatan untuk berpikir menemukan solusi secara individu atas pertanyaan diajukan; (2) 'Pair': siswa secara berpasangan mendiskusikan ide atau gagasan hasil temuan/jawaban akhir dari pertanyaan yang diajukan dan (3) 'Share': membagikan atau mempresentasikan jawaban hasil temuan kepada kelompok lain atau seluruh siswa di kelas".

Pembelajaran model Think Pair Share relatif lebih sederhana karena tidak menyita waktu yang lama untuk mengatur tempat duduk ataupun mengelompokkan siswa. (Firdaus, 


\section{Histogram: Jurnal Pendidikan Matematika, 3 (2), 2019 - 112 Bedilius Gunur, Karolina Santi}

2019), mengatakan bahwa strategi TPS merupakan jenis pembelajaran kooperatif yang dirancang untuk mempengaruhi interaksi siswa. Jadi, TPS merupakan model pembelajaran kooperatif yang efektif yang dapat mempengaruhi interaksi siswa untuk berpikir dan merespon satu sama lain. Hal ini didukung dari penelitian yang dilakukan oleh Khasanah dkk, yang dapat disimpulkan bahwa model pembelajaran Think Pair Share (TPS) dengan pendekatan kontekstual efektif terhadap kemampuan komunikasi matematis peserta didik daripada model pembelajaran ekspositori. Model pembelajaran tipe Think Pair Share (TPS) memberi kesempatan kepada siswa untuk saling membagi ide-ide dan dapat mendorong siswa untuk meningkatkan peran aktif dan kerjasama, juga bertukar pendapat dengan teman untuk mendapatkan kesepakatan dalam menyelesaikan tugas bersama.

\section{METODE PENELITIAN}

Penelitian ini merupakan penelitian eksperimen semu dengan desain penelitian The Non Eqivalen Control Desain. (Fraenkel \& Wallen, 2008; Sugiyono, 2015) mengatakan bahwa penelitian eksperimen semu (quasi experimental designs) merupakan eksperimen yang dilakukan tanpa randomisasi, namun masih menggunakan kelompok kontrol. Penelitian eksperimen merupakan penelitian yang bertujuan untuk menguji pengaruh satu atau lebih dari satu variabel terhadap variabel lain (Creswell, 2012; Sukmadinata 2012; Dell, 2013).

Penelitian ini dilakukan di SMK Santo Aloisius Ruteng. Populasi dalam penelitian ini adalah seluruh siswa kelas XI TP SMK Santo Aloisius Ruteng yang tersebar dalam dua kelas dengan jumlah 60 siswa. Untuk keperluan penelitian, kedua kelas tersebut terlebih dahulu diuji kesetaraannya dengan uji t. Kriteria pengujian jika $t_{\text {hitung }}<t_{\text {tabel }}$ maka kedua kelas memiliki kemampauan yang setara. Hasil analisis menunjukkan nilai $t_{\text {hitung }}=$ $0,720<t_{\text {tabel }}=1,998$ yang berarti setara. Selanjutnya dengan melakukan undian diperoleh kelas TP A yang berjumlah 30 siswa sebagai kelas eksperimen I yang dalam proses pembelajarannya menggunakan model pembelajaran Numbered Head Together (NHT), sedangkan kelas TP B yang berjumlah 30 siswa sebagai kelas eksperimen II, yang dalam proses pembelajarannya menggunakan model pembelajaran Think Pair Share (TPS).

Instrumen yang digunakan untuk pengumpulan data adalah tes kemampuan komunikasi matematis siswa yang berupa pretest dan posttest yang dilaksanakan sebelum dan sesudah proses pembelajaran terdiri dari 4 soal uraian, dan soal disusun berdasarkan indikator kemampuan komunikasi matematis. Sebelum digunakan, instrumen tersebut diuji validitas dan reliabilitasnya. Pengujian validitas instrumen menggunakan rumus korelasi 


\section{Histogram: Jurnal Pendidikan Matematika, 3 (2), 2019 - 113 Bedilius Gunur, Karolina Santi}

product moment. Instrument dikatakan valid apabila $r_{\text {hitung }} \geq r_{\text {tabel }}$ pada taraf signifikan $5 \%$. Ringkasan hasil uji validitas instrument disajikan pada tabel 1 :

Tabel 1. Hasil Uji Validitas Instrumen

\begin{tabular}{llcc}
\hline No & $\mathbf{r}_{\text {hitung }}$ & $\mathbf{r}_{\text {tabel }}$ & Keterangan \\
\hline 1 & 0,589 & 0,381 & Valid \\
\hline 2 & 0,688 & 0,381 & Valid \\
\hline 3 & 0,497 & 0,381 & Valid \\
\hline 4 & 0,569 & 0,381 & Valid \\
\hline
\end{tabular}

(Sumber: Data primer, Tahun: 2019)

Untuk menguji reliabilitas instrumen menggunakan rumus Alpha Cronbach. Hasil uji reliabilitas tes kemampuan komunikasi matematis diperoleh nilai reliabilitas sebesar 0,62 sehingga tes ini dikategorikan memiliki nilai reliabilitas tinggi. Selanjutnya uji hipotesis menggunakan uji t untuk mendeskripsikan: (1) model pembelajaran NHT efektif terhadap kemampuan komuikasi matematis siswa; (2) model pembelajaran TPS efektif terhadap kemampuan komunikasi matematis siswa; (3) model pembelajaran NHT lebih efektif dibandingkan model pembelajaran TPS terhadap kemampuan komunikasi matematis siswa.

\section{HASIL DAN PEMBAHASAN}

Data nilai tes kemampuan komunikasi matematis siswa yang dideskripsikan terdiri dari data pretest dan posttest. Pretest atau tes awal merupakan tes kemampuan komunikasi matematis yang diberikan pada kelas eksperimen I dan kelas eksperimen II sebelum dikenakan perlakuan. Pretest bertujuan untuk mengetahui kemampuan awal siswa berupa tes kemampuan komunikasi matematis pada materi yang dieksperimenkan agar dapat mendeskripsikan peningkatan kemampuan komunikasi matematis siswa dari kelas eksperimen I dan kelas eksperimen II. Sedangkan posttest merupakan tes kemampuan komunikasi yang diberikan pada kelas eksperimen I dan kelas eksperimen II setelah dikenakan perlakuan. Data tersebut dianalisis sehingga diperoleh statistik deskriptif nilai dari kedua kelas tersebut. 
Histogram: Jurnal Pendidikan Matematika, 3 (2), 2019 - 114

Bedilius Gunur, Karolina Santi

Tabel 2. Deskripsi Data Pretest-PosttesKelas Eksperimen I dan II

\begin{tabular}{ccccc}
\hline \multirow{2}{*}{ Nilai Statistika } & \multicolumn{4}{c}{ Kelas } \\
\cline { 2 - 5 } & Eksperimen I & \multicolumn{2}{c}{ Eksperimen II } \\
\hline & Pretest & Posttest & Pretest & Posttest \\
\hline Maksimum $\left(\mathrm{X}_{\text {maks }}\right)$ & 45 & 88 & 45 & 85 \\
\hline Minimum $\left(\mathrm{X}_{\text {min }}\right)$ & 18 & 58 & 15 & 55 \\
\hline Rata-rata & 29 & 75 & 32 & 71 \\
\hline Varians & 39 & 72 & 51 & 68 \\
\hline Standar Deviasi $(\mathrm{S})$ & 6 & 9 & 7 & 8 \\
\hline
\end{tabular}

(Sumber: Data primer, Tahun: 2019)

Hasil statistik deskriptif sebagaimana yang tertera pada tabel 2 memperlihatkan nilai rata-rata pretest antara kelas eksperimen I dan kelas eksperimen II tidak menunjukkan selisih yang signifikan. Dengan demikian dapat dikatakan bahwa kedua kelas memiliki kemapuan komunikasi awal yang setara. Sedangkan nilai rata-rata hasil posttest pada kelas eksperimen I dan kelas eksperimen II juga tidak menunjukan perbedaan yang signitifikan, dimana selisih nilai rata-rata kedua kelompok tersebut adalah 4. Data frekuensi nilai posttest kelas eksperimen I dan kelas eksperimen II dapat dilihat dalam diagram 1:

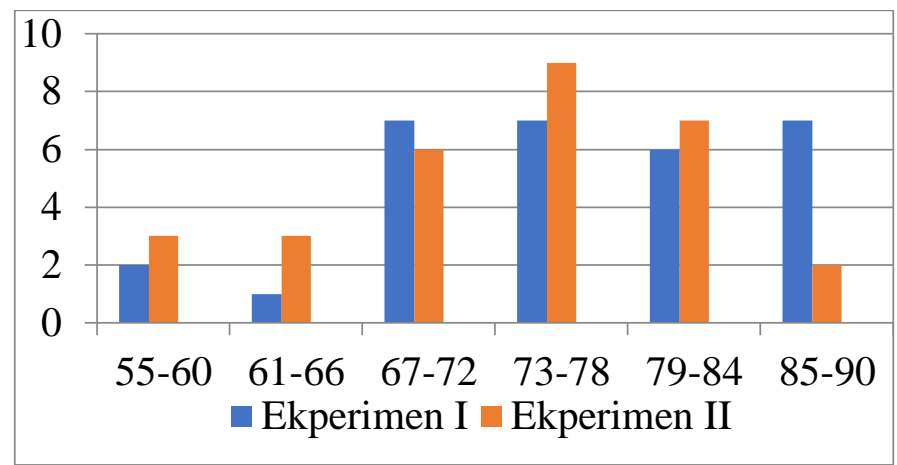

Gambar 1. Diagram Batang Posttest Kelas Eksperimen

Untuk mendeskripsikan peningkatan kemampuan komunikasi matematis siswa yang terjadi sebelum dan sesudah proses pembelajaran, maka rata-rata nilai tes kemampuan komunikasi matematis siswa kelas eksperimen I dan kelas eksperimen II dianalisis dengan menggunakan rumus gain skor ternormalisasi. Deskripsi data gain skor ternormalisasi yang dilakukan meliputi nilai rata-rata, simpangan baku, dan varians.

Tabel 3. Deskripsi Data Gain Skor Ternormalisasi Kelas Eksperimen I dan II

\begin{tabular}{lcccccc}
\hline \multicolumn{1}{c}{ Kelas } & $\mathbf{N}$ & $\begin{array}{c}\text { Nilai } \\
\text { Minimum }\end{array}$ & $\begin{array}{c}\text { Nilai } \\
\text { Maksimum }\end{array}$ & $\begin{array}{c}\text { Rata- } \\
\text { rata }\end{array}$ & $\begin{array}{c}\text { Standar } \\
\text { Deviasi }\end{array}$ & Varians \\
\hline Eksperimen I & 30 & 0,33 & 0,83 & 0,65 & 0,12 & 0,02 \\
\hline Eksperimen II & 30 & 0,38 & 0,76 & 0,59 & 0,11 & 0,01 \\
\hline
\end{tabular}

(Sumber: Data primer, Tahun: 2019) 
Tabel 3 memperlihatkan bahwa nilai rata-rata gain skor ternormalisasi yang diperoleh siswa kelas eksperimen sebesar 0,65 sedangkan nilai rata-rata gain siswa kelas kontrol sebesar 0,59 artinya rata-rata gain skor pada kelas eksperimen I lebih tinggi dari kelas eksperimen II. Hal ini menunjukkan rata-rata kemampuan komunikasi matematis dengan model pembelajaran kooperatif NHT lebih efektif daripada kemampuan komunikasi matematis dengan model pembelajaran TPS.

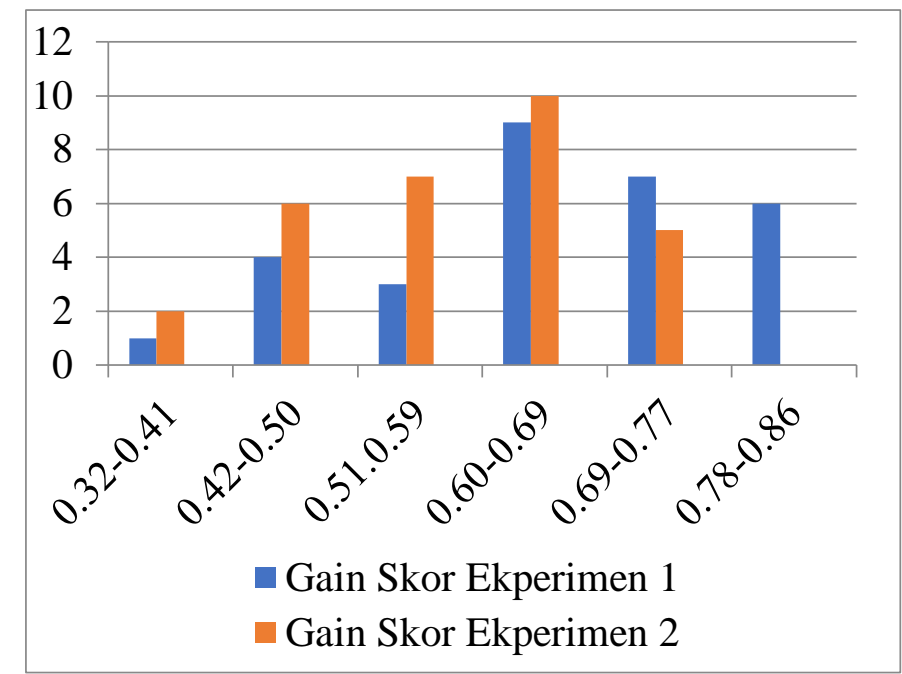

Gambar 2. Diagram Gain Skor Kelas Eksperimen I dan Eksperimen II

Tabel 4. Klasifikasi data Gain Skor

\begin{tabular}{cccc}
\hline Kelas & Rentang skor & Jumlah Siswa & Kategori \\
\hline Eksperimen I & $g \geq 0,70$ & 12 & Tinggi \\
\hline & $0,3 \leq g<0,70$ & 18 & Sedang \\
\cline { 2 - 4 } & $0,3<g$ & - & Rendah \\
\hline Eksperimen II & $g \geq 0,70$ & 4 & Tinggi \\
\hline & $0,3 \leq g<0,70$ & 26 & Sedang \\
\hline & $0,3<g$ & - & Rendah \\
\hline
\end{tabular}

(Sumber: data primer, Tahun: 2019)

Dari tabel 4 tampak bahwa siswa kelas eksperimen I yang gain skornya dalam kategori sedang adalah 18 orang dan kategori tinggi sebanyak 12 orang. Sedangkan pada kelas eksperimen II, siswa yang gain skornya dalam kategori sedang adalah 26 orang dan kategori tinggi sebanyak 4 orang. Hal ini menunjukkan siswa yang mengikuti pembelajaran NHT lebih banyak yang berhasil dibandingkan dengan siswa yang mengikuti pembelajaran TPS.

Data kategori gain skor kelas eksperimen I dan kelas eksperimen II dapat dilihat dalam masing-masing diagram 3: 


\section{Histogram: Jurnal Pendidikan Matematika, 3 (2), 2019 - 116 Bedilius Gunur, Karolina Santi}

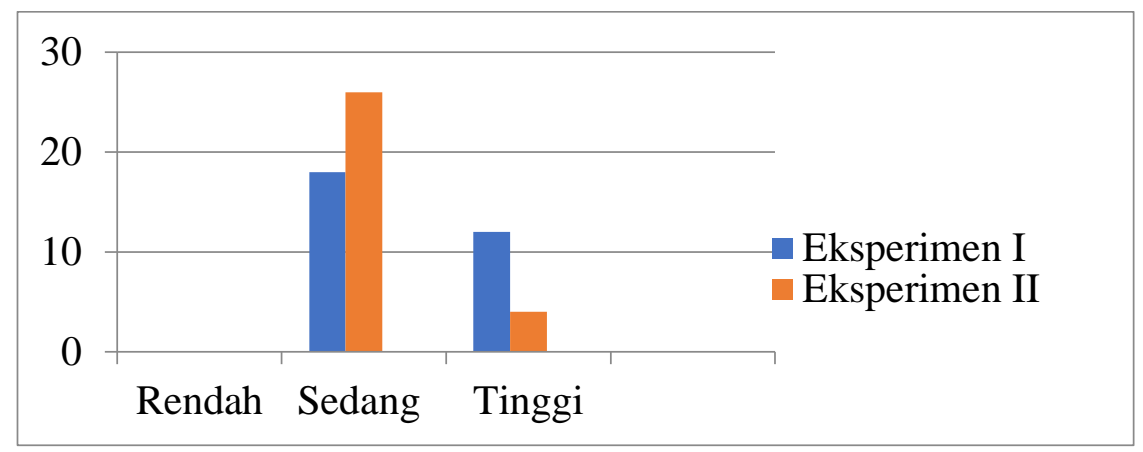

Gambar 3. Diagram Batang Kategori Gain

Sebelum melakukan uji hipotesis, terlebih dahulu dilakukan uji normalitas data dan uji homogenitas data. Hasil perhitungan uji normalitas data pretest kelas eksperimen I diperoleh nilai $\chi^{2}{ }_{\text {hitung }}=3,696$ dan $\chi_{\text {tabel }}^{2}=7,815$, kelas eksperimen II diperoleh nilai $\chi_{\text {hitung }}^{2}=6,563$ dan $\chi_{\text {tabel }}^{2}=7,815$ pada taraf signifikansi $\alpha=0,05$. Hasil perhitungan uji normalitas data postest kelas eksperimen I diperoleh nilai $\chi^{2}{ }_{\text {hitung }}=$ 4,082 dan $\chi_{\text {tabel }}^{2}=7,815$, kelas eksperimen II diperoleh nilai $\chi_{\text {hitung }}^{2}=3,381$ dan $\chi_{\text {tabel }}^{2}=7,815$, pada taraf signifikansi $\alpha=0,05$. Hasil perhitungan uji normalitas data gain kelas eksperimen I diperoleh nilai $\chi_{\text {hitung }}^{2}=4,163$ dan $\chi_{\text {tabel }}^{2}=7,815$, kelas eksperimen II diperoleh nilai $\chi_{\text {hitung }}^{2}=3,050$ dan $\chi_{\text {tabel }}^{2}=7,815$, pada taraf signifikansi $\alpha=0,05$.

Tabel 5. Hasil uji normalitas data pretest, postest, dan gain kelas eksperimen I dan kelas eksperimen II.

\begin{tabular}{ccccc}
\hline \multicolumn{5}{c}{ Data Pretest } \\
\hline Kelas & $\mathrm{N}$ & $\chi^{2}{ }_{\text {hitung }}$ & $\chi^{2}$ tabel & Kesimpulan \\
\hline Eksperimen I & 30 & 3,696 & 7,815 & Normal \\
\hline Eksperimen II & 30 & 6,563 & 7,815 & Normal \\
\hline \multicolumn{5}{c}{ Data Posttest } \\
\hline Kelas & $\mathrm{N}$ & $\chi^{2}{ }_{\text {hitung }}$ & $\chi^{2}{ }_{\text {tabel }}$ & Kesimpulan \\
\hline Eksperimen I & 30 & 4,082 & 7,815 & Normal \\
\hline Eksperimen II & 30 & 3,381 & 7,815 & Normal \\
\hline Kelas & $\mathrm{N}$ & $\chi^{2}{ }_{\text {hitung }}$ & $\chi^{2}{ }_{\text {tabel }}$ & Kesimpulan \\
\hline Eksperimen I & 30 & 4,163 & 7,815 & Normal \\
\hline Eksperimen II & 30 & 3,050 & 7,815 & Normal \\
\hline
\end{tabular}

(Sumber: data primer, Tahun: 2019)

Uji homogenitas sebaran data dalam penelitian ini dianalisis dengan menggunakan uji Fisher. Dari hasil uji homogenitas sebaran data pretest pada kelas eksperimen I dan 


\section{Histogram: Jurnal Pendidikan Matematika, 3 (2), 2019 - 117 Bedilius Gunur, Karolina Santi}

kelas eksperimen II, diperoleh nilai $f_{\text {hitung }}=1,299$ dan nilai $f_{\text {tabel }}=1,841$ pada taraf signifikan $\alpha=5 \%$. Dari hasil uji homogenitas sebaran data posttest pada kelas eksperimen I dan kelas eksperimen II, diperoleh nilai $f_{\text {hitung }}=1,059$ dan nilai $f_{\text {tabel }}=1,841$ pada taraf signifikan $\alpha=5 \%$. Sedangkan hasil homogenitas sebaran data gain pada kelas eksperimen I dan kelas eksperimen II, diperoleh nilai $f_{\text {hitung }}=1,248$ dan nilai $f_{\text {tabel }}=$ 1,841 pada taraf signifikan $\alpha=5 \%$.

Tabel 6. Hasil perhitungan uji homogenitas data gain ternormalisasi, pretest, dan postest kelas eksperimen I dan kelas eksperimen II.

\begin{tabular}{|c|c|c|c|}
\hline \multicolumn{4}{|c|}{ Data Pretest } \\
\hline Kelas & $\mathbf{F}_{\text {hitung }}$ & $\mathbf{F}_{\text {tabel }}$ & Kesimpulan \\
\hline Eksperimen I & \multirow{2}{*}{1,299} & \multirow{2}{*}{1,841} & \multirow{2}{*}{ Homogen } \\
\hline Eksperimen II & & & \\
\hline \multicolumn{4}{|c|}{ Data Posttest } \\
\hline Kelas & $\mathbf{F}_{\text {hitung }}$ & $\mathbf{F}_{\text {tabel }}$ & Kesimpulan \\
\hline $\begin{array}{l}\text { Eksperimen I } \\
\text { Eksperimen II }\end{array}$ & 1,059 & 1,841 & Homogen \\
\hline \multicolumn{4}{|c|}{ Data Gain } \\
\hline Kelas & $\mathbf{F}_{\text {hitung }}$ & $\mathbf{F}_{\text {tabel }}$ & Kesimpulan \\
\hline $\begin{array}{l}\text { Eksperimen I } \\
\text { Eksperimen II }\end{array}$ & 1,248 & 1,841 & Homogen \\
\hline
\end{tabular}

(Sumber: data primer, Tahun: 2019)

Karena $f_{\text {hitung }}<f_{\text {tabel }}$, maka $\mathrm{H}_{0}$ diterima, artinya kelompok eksperimen I dan eksperimen II memiliki varians yang sama atau homogen. Hasil perhitungan uji normalitas dan uji homogenitas data kemampuan komunikasi matematis terpenuhi maka dapat dilanjutkan dengan uji hipotesis menggunakan uji t.

Tabel 7. Hasil Uji Data Posstest dengan Model Pembelajaran NHT

\begin{tabular}{|c|c|c|c|c|}
\hline Kelas & $\mathbf{N}$ & $t_{\text {hitung }}$ & $t_{\text {tabel }}$ & Kesimpilan \\
\hline Eksperimen I & 30 & 6199 & 2045 & Menolak H0 dan \\
\hline Eksperimen II & 30 & & & menerima $\mathrm{H} 1$ \\
\hline
\end{tabular}

(Sumber: Data primer, Tahun: 2019)

Tabel 8. Hasil Uji Data Posstest dengan Model Pembelajaran TPS

\begin{tabular}{|c|c|c|c|c|}
\hline Kelas & $\mathbf{N}$ & $t_{\text {hitung }}$ & $t_{\text {tabel }}$ & Kesimpilan \\
\hline $\begin{array}{l}\text { Eksperimen I } \\
\text { Eksperimen II }\end{array}$ & $\frac{30}{30}$ & 4,455 & 2,045 & $\begin{array}{l}\text { Menolak H0 dan } \\
\text { menerima H1 }\end{array}$ \\
\hline
\end{tabular}

(Sumber: Data primer, Tahun: 2019) 


\section{Histogram: Jurnal Pendidikan Matematika, 3 (2), 2019 - 118 Bedilius Gunur, Karolina Santi}

Tabel 9. Hasil Uji-t Data Gain Skor Ternormalisasi

\begin{tabular}{llcclc}
\hline \multicolumn{1}{c}{ Kelas } & $\mathbf{N}$ & $\boldsymbol{t}_{\text {hitung }}$ & $\boldsymbol{t}_{\text {tabel }}$ & \multicolumn{2}{c}{ Kesimpilan } \\
\hline Eksperimen I & 30 & 2,055 & 2,002 & $\begin{array}{l}\text { Menolak H0 dan } \\
\text { menerima H1 }\end{array}$ \\
\hline Eksperimen II & 30 & 2,05 & 2,00 &
\end{tabular}

(Sumber: Data primer, Tahun: 2019)

Dari data pada tabel di atas, diperoleh hasil perhitungan $t_{\text {hitung }}=6,199$, harga $t_{\text {tabel }}=2,045, t_{\text {hitung }}=4,455$, harga $t_{\text {tabel }}=2,045$, dan $t_{\text {hitung }}=2,055$, harga $t_{\text {tabel }}=2,002$, dengan demikian, karena $t_{\text {hitung }}>t_{\text {tabel }}$, maka $H_{0}$ ditolak dan $H_{1}$ diterima, artinya model pembelajaran kooperatif tipe Number Head Together efektif terhadap kemampuan komunikasi matematis, model pembelajaran kooperatif tipe Think Pair Share efektif terhadap kemampuan komunikasi matematis, dan model pembelajaran kooperatif tipe Number Head Together lebih efektif daripada model pembelajaran kooperatif tipe Think Pair Share terhadap kemampuan komunikasi matematis. Hasil analisis data juga menunjukkan bahwa terdapat peningkatana kemampuan komunikasi matematis siswa kelas eksperimen I lebih tinggi dibanding dengan kelompok eksperimen II setelah perlakuan. Rata-rata hasil belajar siswa kelas SMK Aloisius Ruteng sebelum menggunakan model Number Head Togeter tidak memenuhi Ketuntasan Kriteria Minimal (KKM), begitupun sebelum menggunakan Think Pair Share dimana KKM yang dimaksud $=65$, namun setelah penerapan kedua model tersebut terjadi peningkatan diatas KKM.

Perbedaan keefektifan kemampuan komunikasi matematis diakibatkan oleh beberapa faktor. Salah satunya adalah langkah-langkah pembelajaran yang berbeda. Model Number Head Together (NHT) dan Think Pair Share (TPS) sama-sama merupakan model pembelajaran berkelompok namun dalam pelaksanaan pembelajarannya memiliki perbedaan. Pelaksanaan pembelajaran TPS menekankan pola interaksi siswa dalam bentuk diskusi untuk merespon satu sama lain dalam proses belajar. Hal ini sejalan dengan pendapat Trianto (2012) bahwa strategi TPS merupakan jenis pembelajaran kooperatif yang dirancang untuk mempengaruhi pola interaksi siswa. Dalam proses pembelajaran berlangsung dengan model pembelajaran TPS, terutama dalam mempresentasikan dan mempertanggungjawabkan ide dan hasil diskusi, sudah ditentukan terlebih dahulu siapa yang dipercayakan untuk mewakili setiap pasangan. Dalam model pembelajaran ini, banyak pasangan yang dibentuk, sehingga hanya beberapa perwakilan pasangan yang dapat mempresentasikan hasil diskusi, karena waktu terbatas. 


\section{Histogram: Jurnal Pendidikan Matematika, 3 (2), 2019 - 119 \\ Bedilius Gunur, Karolina Santi}

Sementara, model pembelajaran NHT juga menekankan pada struktur khusus yang dirancang untuk mempengaruhi pola interaksi siswa dan memiliki tujuan untuk meningkatkan tanggung jawab individu dalam kelompok. Dalam proses pembelajaran yang menggunakan model pembelajaran NHT, seluruh siswa dibagi ke dalam beberapa kelompok, dimana setiap kelompok akan ditempati oleh siswa yang terdiri dari 4-5 orang. Dalam kelas NHT setiap siswa dalam satu kelompok akan mendapatkan penomoran individu, yang bertujuan untuk memudahkan guru dalam mengontrol pelaksanaan pembelajaran. Pemilihan nomor secara acak menuntut setiap siswa untuk selalu siap mempertanggungjawabkan atau mempresentasikan hasil diskusi kepada seluruh siswa di kelas. Jadi setiap anggota kelompok selalu siap. Hal ini menjadi keunggulan dari model pembelajaran NHT. Seperti yang diutarakan (Yustitia, 2017) NHT pada dasarnya merupakan sebuah variasi diskusi kelomok, ciri khasnya adalah guru hanya menunjuk seorang siswa yang mewakil kelompoknya, tanpa memberi tahu terlebih dahulu siapa yang akan mewakil kelompoknya itu. Dengan cara ini menjamin keterlibatan total semua siswa dan meningkatkan tanggung jawab individual dalam diskusi.

\section{KESIMPULAN DAN SARAN}

\section{A. Kesimpulan}

Berdasarkan pada uraian sebelumnya, hasil penelitian dapat disimpulkan; 1) Model pembelajaran kooperatif tipe Number Head Together (NHT) efektif terhadap kemampuan komunikasi matematis siswa kelas XI Teknik Pengelasan SMK Aloisius Ruteng;2) Model pembelajaran kooperatif tipe Think Pair Share (TPS) efektif terhadap kemampuan komunikasi matematis siswa kelas XI Teknik Pengelasan SMK Aloisius Ruteng; 3) Model pembelajaran kooperatif tipe Number Head Together (NHT) lebih efektif daripada model pembelajaran kooperatif tipe Think Pair Share (TPS) terhadap kemampuan komunikasi matematis siswa kelas XI Teknik Pengelasan SMK Aloisius Ruteng.

\section{B. Saran}

Hasil penelitian ini dapat menjadi dasar pertimbangan bagi guru matematika dalam menggunakan model pembelajaran kooperatif tipe NHT dan TPS untuk meningkatkan kemampuan komunikasi matematis siswa. Kedua model ini juga dapat diteliti lebih lanjut sebagai model pembelajaran alternatif dalam mengembangkan kemampuan matematis lainnya. 


\section{Histogram: Jurnal Pendidikan Matematika, 3 (2), 2019 - 120 \\ Bedilius Gunur, Karolina Santi}

\section{DAFTAR PUSTAKA}

Abdul, Q., \& Sumarmo, U. (2013). Improving Mathematical Communication Ability and Self Regulation Learning Of Yunior High Students by Using Reciprocal Teaching. IndoMS. J.M.E, 4(1), 59-74.

Asnawati, S. (2013). Peningkatan Kemampuan Komunikasi Matematis Siswa SMP Dengan Pembelajaran Kooperatif Tipe Teams-Games- Tournaments. Jurnal Euclid, 3(2), 561-567.

Creswell, J. W. (2012). Educational Research: Planning, Conducting, and Evaluating Quantitative and Qualitative Research (FOURTH EDI; M. Buchholtz, Ed.). Boston.

Dell, T. F. (2013). A Descriptive Study of Students with Disabilities at Montana State University Billings. Montana State University.

Firdaus, A. M. (2019). Application of cooperative learning model type think pair share (tps) on mathematical communication ability. DAYA MATEMATIS: Jurnal Inovasi Pendidikan Matematika, 7(1), 59-68.

Fraenkel, J. R., \& Wallen, N. E. (2008). How to Design and Evaluate Research in Education (SEVENTH ED; M. Ryan, Ed.). San Francisco: Beth Mejia.

Gunur, B., Makur, A. P., \& Ramda, A. H. (2018). Hubungan antara kemampuan numerik dengan kemampuan pemecahan masalah matematis siswa di pedesaan. MaPan: Jurnal Matematika Dan Pembelajaran, 6(2), 148-160.

Gunur, B., Ramda, A. H., \& Makur, A. P. (2019). Vocational School Students' Mathematical Connections In Cooperative Learning With Open Ended Approach. Daya Matematis : Jurnal Inovasi Pendidikan Matematika, 7(2), 127-138.

Hadi, S., \& Kasum, M. U. (2015). Pemahaman konsep matematika siswa smp melalui penerapan model pembelajaran kooperatif tipe memeriksa berpasangan (pair checks). EDU-MAT Jurnal Pendidikan Matematika, 3(April), 59-66.

Hirschfeld-cotton, K. (2008). Mathematical Communication, Conceptual Understanding , and Students' Attitudes Toward Mathematics.

Kusuma, A. P., \& Maskuroh, M. (2018). The Differences of Mathematics Learning Outcomes between Think Pair Share (TPS) and Number Heads Together (NHT). AlJabar: Jurnal Pendidikan Matematika, 9(1), 19-24.

Lee, C., Li, H.-C., \& Shahrill, M. (2018). Utilising the Think-Pair-Share Technique in the Learning of Probability. International Journal on Emerging Mathematics Education (IJEME), 2(1), 49-64.

Marthaulina, M., Siahaan, L., \& Napitupulu, E. E. (2012). The Difference of Students ' Mathematical Communication Ability Taught by Cooperative Learning Model Think Talk Write Type and Numbered Head Together Type. Scholaria: Jurnal Pendidikan Dan Kebudayaan, 231-242.

Miratika, Asmin, Mulyono, \& Minarni, A. (2018). The Effect Of Cooperative Learning of Type Think Pair Share Based on Mandailing Culture To Mathematical Problem Solving Ability Of The Students at MSS Ali Imron Medan. Advances in Social Sciences Research Journal, 5(10), 320-330.

Muchlis, A., Komara, E. S., Kartiwi, W., Hendriana, H., \& Hidayat, W. (2018). Meningkatkan Koneksi Matematis Siswa SMP Melalui Pendekatan Open-Ended Dengan Setting Kooperatif Tipe. KALAMATIKA Jurnal Pendidikan Matematika, $3(1), 81-92$.

NCTM. (2000). Principles and Standards for School Mathematics. 


\section{Histogram: Jurnal Pendidikan Matematika, 3 (2), 2019 - 121 Bedilius Gunur, Karolina Santi}

Pratiwi, D. D. (2015). Analisis Kemampuan Komunikasi Matematis dalam Pemecahan Masalah Matematika Sesuai dengan Gaya Kognitif dan Gender Dona Dinda Pratiwi. Al-Jabar: Jurnal Pendidikan Matematika, 6(2), 131-141.

Purnama, I. L., Aldila, E., \& Stkip, A. (2016). Kemampuan Komunikasi Matematis Siswa Ditinjau Melalui Model Pembelajaran Kooperatif Tipe Complete Sentence. Jurnal Pendidikan Matematika, 10(1), 27-43.

Rahmi, S., Nadia, R., Hasibah, B., \& Hidayat, W. (2017). The Relation Between SelfEfficacy Toward Math With The Math Communication. Journal of Mathematics Education, 6(2), 177-182. https://doi.org/10.22460/infinity.v6i2.p177-182

Sugiyono. 2015. Metode Penelitian Kuantitatif, Kualitatif, dan Kombinasi (Mixed Methods). Bandung: Alfabeta.

Sukmadinata. 2012. Metode Penelitian Pendidikan. Bandung: PT Remaja Rosdakarya

Supriyadi, E. W. A., Suharto, \& Hobri. (2017). Analisis Kemampuan Koneksi Matematis Berdasarkan NCTM (National Council of Mathematics) Siswa SMK Kelas XI Jurusan Multimedia Pada Pokok Bahasan Hubungan Antar Garis. Kadikma, 8(1), 128-136. https://doi.org/10.1016/j.physb.2015.01.016

Surya, E., Juniati, N., \& Syahputra, E. (2018). Effect of Problem Based Learning Toward Mathematical Communication Ability and Self-Regulated Learning. Journal of Education and Practice, 9(6), 14-23.

Trianto. 2013. Mendesain Model Pembelajaran Inovatif, Progresif, Konsep, Landasan, dan Implementasinya Pada Kurikulum Tingkat Satuan Pendidikan (KTSP). Jakarta: Kencana Prenada Media Group

Yustitia, V. (2017). Comparison of Students' Reasoning Skills between "Numbered Head Together" and "Think Pair Share" Based on Portfolio. Advances in Social Science, Education and Humanities Research (ASSEHR), 158(Ictte), 790-794. 